\title{
THE ROLE OF HILAR LYMPHADENECTOMY IN PATIENTS SUBJECTED TO HEPATECTOMY DUE TO COLORECTAL METASTASIS
}

\author{
Eduardo Freitas VIANA, Paulo HERMAN, Fabrício Ferreira COELHO, \\ Thomas Augusto TAKA, Luiz A. Carneiro D’ALBUQUERQUE and Ivan CECCONELLO
}

\begin{abstract}
Context - Hepatectomy is the treatment of choice for colorectal liver metastases, and several studies have shown good results, with 5-year survival rates ranging from $40 \%$ to $57 \%$. Several clinical and pathological predictive factors for survival after liver resection have been studied. Involvement of the hepatic hilum lymph nodes, the incidence of which varies from $2 \%$ to $10 \%$, indicates a poor long-term prognosis. Results - Despite variable results, some authors have reported a not-insignificant improvement in survival rate in liver-metastasis patients with hilar lymph node involvement who undergo combined liver resection and lymphadenectomy. Due to the low rates of morbidity and mortality for liver-resection surgery, several specialized centers perform liver resections combined with lymphadenectomies in selected cases. It should be noted that the therapeutic value of systemic lymphadenectomy is not yet entirely understood, and only controlled studies comparing groups with and without lymphadenectomy can fully resolve the issue. Conclusion - In any case, hilar lymph node dissection has been shown to be a useful tool for improving the accuracy of extra hepatic disease staging, regardless of its impact on survival.
\end{abstract}

HEADINGS - Neoplasm metastasis. Lymph node excision. Hepatectomy. Colorectal neoplasms.

\section{INTRODUCTION}

Liver resection is the treatment of choice for colorectal liver metastases, and several studies have shown long-term survival rates ranging from $40 \%$ to $57 \%$. Many predictive factors for survival after liver resection have been studied, and hilar lymph node involvement, which is present in $2 \%$ to $10 \%$ of the cases, is associated with a poor prognosis. Although the results have been variable, some authors have shown long-term survival in liver-metastasis patients with hilar-lymph-node involvement who undergo liver resection and hilar lymphadenectomy. Due to the low rates of morbidity and mortality for liverresection surgery, several specialized centers perform liver resections combined with lymphadenectomies in selected cases. The therapeutic value of systemic lymphadenectomy is not yet entirely understood, and only controlled studies comparing groups with and without lymphadenectomy can fully resolve the issue. However, hilar lymphadenectomy is a useful tool for improving extra hepatic-tumor staging independently of its impact on survival. The authors performed a review of systematic lymphadenectomy in patients who have undergone liver resection for colorectal cancer metastases.

Hepatectomy is currently the treatment of choice for hepatic metastases of colorectal cancer, and several studies have shown good results, with 5-year survival rates ranging from $40 \%$ to $57^{(1,2,3,5,12)}$.

Several clinical and pathological predictive factors for survival after hepatic resection have been studied. These factors include the locoregional staging of the primary tumor, the presence or absence of extrahepatic disease, the interval between the diagnoses of the primary and the metastatic lesions, the preoperative level of carcinoembryonic antigen and the lymph-node involvement of the hepatic hilum. Despite some discrepancies in results, most studies have shown that lymph-node involvement at the primary site, synchronicity of the lesions, four or more hepatic lesions, and hilar lymph node metastases constitute the major negative prognostic factors, with significant impacts on long-term survival ${ }^{(3,28,31,30)}$.

It is believed that lymph-node involvement in patients with colorectal liver metastases may actually constitute a tertiary metastasis or "metastasis of a metastasis", a concept proposed by August et al. ${ }^{(6)}$ in 1985 and subsequently reinforced by other studies ${ }^{(10,15)}$. The prevalence of macroscopic lymph node involvement in the hepatic hilum of patients with colorectal liver metastases varies between $2 \%$ and $10 \%$ in major series ${ }^{(6,}$ $7,12,29)$, and they generally indicate a poor long-term prognosis. Based on these results, most authors have considered macroscopic lymph node involvement to be a contraindication to liver resection ${ }^{(13,22,32)}$. It

Department of Gastroenterology - University of São Paulo Medical School, São Paulo, SP, Brazil.

Correspondence: Prof. Paulo Herman - Praça Santos Coimbra, 10 - 05614-050 - São Paulo, SP, Brasil. E-mail: pherman@uol.com.br 
should be remembered, however, that assessments based only on palpation and macroscopic inspection (the procedures used by most surgeons), and those based on an examination of frozen lymph-node sections suspected of metastatic involvement, are not accurate. Studies that have employed systematic dissection of suspicious and non-suspicious hilar lymph nodes to diagnose microscopic involvement have found an incidence of $15 \%{ }^{(11,20)}$. Studies that have examined the impact of microscopic lymph-node involvement on survival have found it to have a negative effect. Thus, the relevant question is whether hepatic resection is indicated in patients with affected hilar lymph nodes?

Despite a certain amount of controversy, some authors have reported significant survival rates in liver-metastasis patients with associated hilar-lymph-node disease who undergo combined liver resection and lymphadenectomy ${ }^{(7 .}$ 9, 16, 17, 25). Among those results, Kokudo et al. ${ }^{(19)}$ have shown that the survival rate of patients with lymph node disease who undergo curative resection and lymphadenectomy is significantly higher than that of residual-liver-disease patients without lymph-node metastases who undergo liver resection $(17$ months versus 8 months, $P<0.05)$. These authors therefore suggest a possible benefit from resection and hilar lymphadenectomy in patients with lymph node involvement ${ }^{(7)}$. Two other studies have found 3 -year survival rates between $38 \%$ and $45 \%$ in patients with compromised liver pedicle lymph nodes who undergo liver resection combined with lymphadenectomy. However, the authors call attention to the location of the compromised lymph nodes: when they are located near the hilum, the resection may offer long-term survival benefits, but when they are near the common hepatic artery or celiac trunk, the longterm survival is significantly worse ${ }^{(16,17)}$. These authors emphasize that proximal lymph node involvement is not a contraindication to hepatectomy, which they defend under those circumstances. Recently, Adam et al.(4) described an 18\% global 5-year survival rate in a selected group of patients with hepatic metastases and compromised hepatic hilar lymph nodes who underwent hepatic resection and lymphadenectomy. Due to the low rates of morbidity and mortality for liver-resection surgery, several specialized centers (including our facility) perform liver resections combined with lymphadenectomies in selected cases.

It should be noted that the therapeutic value of systemic lymphadenectomy is not yet entirely understood, and that only controlled studies comparing groups with and without lymphadenectomy can fully resolve the issue. In any case, hilar lymph node dissection has been shown to be a useful tool for improving the accuracy of extra hepatic disease staging, regardless of its impact on survival.

Recently, a microscopic study at our facility on lymph-node micrometastases, in patients without macroscopic lymph-node disease who undergo hepatic resection and lymphadenectomy, showed involvement of the hilar lymph nodes (including micrometastases) in $18 \%$ of the patients, which confirms the hypothesis that an examination restricted to the radiological and macroscopic aspects is inadequate as a complete evaluation and that lymph node dissection can improve the staging accuracy $^{(33)}$. Moreover, lymph-node evaluation through multiple serial sections followed by immunohistochemistry staining using human pancytokeratin AE1/AE3 antibody detected a further $10.8 \%$ of the patients with micrometastases, all of whom were negative by conventional methods. Thus, the immunohistochemistry method was shown to increase the detection of affected lymph-nodes ${ }^{(33)}$. In a recent study, Bennet et al. ${ }^{(8)}$ similarly used serial thin sections followed by immunohistochemistry in patients with colorectal hepatic metastases and diagnosed micrometastases in $24 \%$ of the samples. Micrometastases research has been routinely used in breast cancer and melanoma cases ${ }^{(14,17,18,23,24)}$, and several studies on other malignancies have confirmed that it expands the diagnostic sensibility ${ }^{(21,26,27)}$.

From a practical perspective, the clinical importance of lymph node micrometastases for long-term survival is not known, especially in patients undergoing systemic treatment (chemotherapy). There is a dearth of studies evaluating whether detecting micrometastases only allows for better staging, is indicative of a poor prognosis, or has limited prognostic value. Despite some authors having shown a correlation between the major prognostic factors and the presence of lymph node metastases ${ }^{(11,17)}$, most studies have not found such associations and have reaffirmed the impossibility of determining risk subgroups for hilar lymph node involvement $\mathrm{t}^{(8,19,20,33)}$.

A controversial issue is the role of lymph node dissection in major-chain sampling without a complete dissection of the hepatic hilum and the celiac trunk. In 1999, Kokudo et al. ${ }^{(19)}$ used this method to show a tendency towards $12 \mathrm{~B}$ chain involvement in patients with metastases on the right side and towards $8 \mathrm{~A}$ chain involvement in lesions located on the left side. Based on these findings, the authors concluded that this sampling method is effective for determining the lymph node status of a patient. However, other authors have not found a relationship between the chains involved and the topography of the hepatic lesions ${ }^{(7,11,17,20)}$. In 1996, Elias et al. ${ }^{(11)}$ diagnosed microscopic lymph-node involvement in several of the lymphatic chains studied without a continuous progression from one chain to another (lymph-node-jumping metastasis). Therefore, any specific lymph-node group will reflect the true state of ganglion involvement in patients with metastatic hepatic lesions.

Finally, it is important to highlight the possible role of systemic treatment in patients with macroscopic or microscopic lymph-node disease who undergo resection and lymphadenectomy. It is presumed that modern chemotherapy procedures, either preoperatively or as an adjuvant, can positively influence the clinical course of these patients, possibly creating a new paradigm for the treatment of colorectal liver metastases and extending the limits of liver resection, even in patients with lymph node involvement. However, controlled studies that compare groups with and without lymphadenectomies are required to obtain more consistent results and determine the real survival value of the procedure in patients with resectable colorectal liver metastases. 
Viana EF, Herman P, Coelho FF, Taka TA, D’Albuquerque LAC, Cecconello I. Papel da linfadenectomia hilar em pacientes submetidos a hepatectomia por metástases colorretais. Arq Gastroenterol. 2011;48(3):217-9.

RESUMO - Contexto - A hepatectomia é o tratamento de eleição para metástases hepáticas de câncer colorretal e diversos estudos têm demonstrado bons resultados, com índices de sobrevida em 5 anos entre $40 \%$ e $57 \%$. Vários fatores clínico-patológicos preditivos de sobrevida após a ressecção hepática têm sido estudados e o envolvimento linfonodal do hilo hepático, que varia entre $2 \%$ e $10 \%$, confere a este grupo prognóstico reservado a longo prazo. Resultados - Embora com resultados variáveis, alguns autores têm relatado sobrevida não desprezível em pacientes com metástases hepáticas associada à doença linfonodal hilar submetidos a hepatectomia conjuntamente à linfadenectomia. Muitos centros especializados, embasados nos baixos índices de morbimortalidade da hepatectomia, realizam a ressecção hepática associada à linfadenectomia em casos selecionados. Cumpre ressaltar que o valor terapêutico da linfadenectomia sistemática ainda não é inteiramente conhecido e somente estudos controlados, comparando grupos com e sem linfadenectomia, poderão dirimir estas questões. Conclusão - De qualquer forma, a dissecção linfonodal hilar demonstrou ser uma ferramenta que torna mais preciso o estadiamento da doença extra-hepática, independente do impacto deste procedimento na sobrevida.

DESCRITORES - Metástase neoplásica. Linfadenectomia. Hepatectomia. Câncer colorretal.

\section{REFERENCES}

1. Abdalla EK, Vauthey JN, Ellis LM, Ellis V, Pollock R, Broglio KR, Hess K, Curley SA. Recurrence and outcomes following hepatic resection, radiofrequency ablation, and combined resection/ablation for colorectal liver metastases. Ann Surg. 2004;239:818-25

2. Abdalla EK, Vauthey JN. Improved survival after resection of colorectal liver metastases. J Clin Oncol. 2006;24:2679-81.

3. Adam R, Bismuth H, Castaing D, Waechter F, Navarro F, Abascal A, Majno P, Engerran L. Repeat hepatectomy for colorectal liver metastases. Ann Surg. 1997;225:51-62.

4. Adam R, de Haas RJ, Wicherts DA, Aloia TA, Delvart T, Azoulay D, Bismuth $\mathrm{H}$, Castaing D. Is hepatic resection justified after chemotherapy in patients with colorectal liver metastases and lymph node involvement? J Clin Oncol. 2008;26:3672-80.

5. August DA, Ottow RT, Sugarbaker PH. Clinical perspective of human colorectal cancer metastasis. Cancer Metastasis Rev. 1984;3:303-24.

6. August DA, Sugarbaker PH, Schneider PD. Lymphatic dissemination of hepatic metastases. Implication for the follow-up and treatment of patients with colorectal cancer. Cancer. 1985;55:1490-4.

7. Beckurts KT, Hölscher AH, Thorban S, Bollschweiler E, Siewert JR. Significance of lymph node involvement at the hepatic hilum in the resection of colorectal liver metastases. Br J Surg. 1997;84:1081-4.

8. Bennett JJ, Schmidt CR, Klimstra DS, Grobmyer SR, Ishill NM, D'Angelica M, DeMateo RP, Fong Y, Blumgart LH, Jarnagin WR. Perihepatic lymph node micrometastases impact outcome after partial hepatectomy for colorectal metastases. Ann Surg Oncol. 2008;15:1130-6.

9. Carpizo DR, D'Angelica M. Liver resection for metastatic colorectal cancer in the presence of extrahepatic disease. Ann Surg Oncol. 2009;16: 2411-21.

10. Dworkin MJ, Earlam S, Fordy C, Allen-Mersh TG. Importance of hepatic artery node involvement in patients with colorectal liver metastasis. J Clin Pathol. 1995;48:270-2.

11. Elias D, Saric J, Jaeck D, Arnaud JP, Gayet B, Rivoire M, Lorimier G, Carles J, Lasser P. Prospective study of microscopic lymph node involvement of the hepatic pedicle during curative hepatectomy for colorectal metastases. Br J Surg. 1996;83:942-5.

12. Fong Y, Fortner J, Sun RL, Brennan MF, Blumgart LH. Clinical score for predicting recurrence after hepatic resection for metastatic colorectal cancer: analysis of 1001 consecutive cases. Ann Surg. 1999;230:309-18.

13. Gibbs JF, Weber TK, Rodriguez-Bigas MA, Driscoll DL, Petrelli NJ. Intraoperative determinants of unresectability for patients with colorectal hepatic metastases. Cancer. 1998;82:1244-9.

14. Giuliano AE, Jones RC, Brennan M, Statman R. Sentinel lymphadenectomy in breast cancer. J Clin Oncol. 1997;15:2345-50.

15. Hughes K, Scheele J, Sugarbaker PH. Surgery for colorectal cancer metastatic to the liver. Optimizing the results of treatment. Surg Clin North Am. 1989;69: 339-59.

16. Ishibashi K, Ohsawa T, Yokohama M, Ishizuka N, Miyazaki T, Nakada H, Gonda $\mathrm{T}$, Ishida $\mathrm{H}$. Hepatic lymph node involvement in patients with synchronous multiple liver metastases of colorectal cancer. Gan To Kagaku Pyoho. 2006;33: 1834-7.
17. Jaeck D, Nakano H, Bachellier P, Inoue K, Weber JC, Oussoultzoglou E, Wolf P, Chenard-Neu MP. Significance of hepatic pedicle lymph node involvement in patients with colorectal liver metastases: a prospective study. Ann Surg Oncol. 2002;9:430-8.

18. Karimipour DJ, Lowe L, Su L, Hamilton T, Sondak V, Johnson TM, Fullen D. Standard immunostains for melanoma in sentinel lymph node specimens: which ones are most useful? J Am Acad Dermatol. 2004;50:759-64.

19. Kokudo N, Sato T, Seki M, Ohta K, Azekura K, Ueno M, Matsubara T, Yanagisawa A, Kato Y, Takahashi T. Hepatic lymph node involvement in resected cases of liver metastases from colorectal cancer. Dis Colon Rectum. 1999;42:1285-90.

20. Laurent C, Sa Cunha A, Rullier E, Smith D, Rullier A, Saric J. Impact of microscopic hepatic lymph node involvement on survival after resection of colorectal liver metastasis. J Am Coll Surg. 2004;198:884-91.

21. Maehara Y, Baba H, Ohno, Sugimachi K. Cytokeratin staining reveals micrometastases in lymph nodes of early gastric cancer. Surgery. 1995;117:480.

22. Minagawa M, Makuuchi M, Torzilli, Takayama T, Kawasaki S, Kosuge T, Yamamoto J, Imamura H. Extension of the frontiers of surgical indications in the treatment of liver metastasis from colorectal cancer: long term results. Ann Surg. 2000;231:487-99.

23. Morton DL, Ollila DW. Critical review of sentinel node hypothesis. Surgery. 1999;126:815-9.

24. Mullenix PS, Brown TA, Meyers MO, Giles LR, Sigurdson ER, Borass MC, Hoffman JP, Eisenberg BL, Torosian MH. The association of cytokeratin-onlypositive sentinels lymph nodes and subsequent metastases in breast cancer. Am J Surg. 2005;189:606-9.

25. Nakamura S, Yokoi Y, Suzuki S, Baba S, Muro H. Results of extensive surgery for liver metastasis in colorectal carcinoma. Br J Surg. 1992;79:35-8.

26. Noura S, Yamamoto H, Miyake Y, Kim B, Takayama O, Seshimo I., Ikenaga M, Ikeda M, Sekimoto M, Matsuura N, Monden M. Immunohistochemical assessment of localization and frequency of micrometastases in lymph nodes of colorectal cancer. Clin Cancer Res. 2002;8:759-67.

27. Perez RO, Habr-Gama A, Nishida Arazawa ST, Rawet V, Coelho Siqueira SA, Kiss DR, Gama-Rodrigues JJ. Lymph node micrometastasis in stage II distal rectal cancer following neoadjuvant chemoradiation therapy. Int J Colorectal Dis. 2005;20:434-9.

28. Resection of the liver for colorectal carcinoma metastases: a multi-institutional study of indications for resection. Registry of Hepatic Metastases. Surgery. 1988;103:278-88.

29. Rodgers MS, McCall JL. Surgery for colorectal liver metastasis with hepatic lymph node involvement: a systematic review. Br J Surg. 2000;87:1142-55.

30. Sasaki A, Iwashita Y, Shibata K, Matsumoto T, Ohta M, Kitano S. Analysis of preoperative prognostic for long-term survival after hepatic resection of liver metastasis of colorectal carcinoma. J Gastrointest Surg. 2005;9:374-80.

31. Scheele J, Stangl R, Altendorf-Hofmann, Gall FP. Indicators of prognosis after hepatic resection for colorectal secondaries. Surgery. 1991;110:13-29

32. Scheele J, Stang R, Altendorf-Hofmann, Paul M. Resection of colorectal liver metastasis. World J Surg. 1995;19:59-71.

33. Viana EF, Herman P, Siqueira SC, Taka T, Carvalho P, Coelho FF, Pugliese V, Saad WA, D'Albuquerque LA. Lymphadenectomy in colorectal cancer liver metastases resection: incidence of hilar limph nodes micrometastasis. J Surg Oncol. 2009;100:534-7.

Received 3/5/2010 Accepted 13/8/2010 